ISSN 0258-7122

Bangladesh J. Agril. Res. 36(4): 647-656, December 2011

\title{
EFFECT OF SULPHUR FERTILIZATION ON THE GROWTH AND YIELD OF GARLIC (Allium sativum L.)
}

\author{
M. S. ZAMAN ${ }^{1}$, M. A. HASHEM ${ }^{2}$, M. JAHIRUDDIN ${ }^{2}$ AND M. A. RAHIM ${ }^{3}$
}

\begin{abstract}
The experiment was conducted for two consecutive rabi seasons of 2005-06 and 2006-07 at the Regional Agricultural Research Station (RARS), BARI, Jamalpur to find out an optimum dose of sulphur for yield maximization of garlic cV. Jamalpur local. There were six levels of sulphur viz., $0,15,30,45,60$, and 75 $\mathrm{kg} / \mathrm{ha}$. A control treatment was in the experiment. The experiment was laid out in randomized complete block design with three replications. The fertilizer package $\mathrm{N}_{150} \mathrm{P}_{60} \mathrm{~K}_{120} \mathrm{Zn}_{4} \mathrm{~B}_{1} \mathrm{~kg} / \mathrm{ha}$ was applied to each plot as blanket dose. Results revealed that most of the growth and yield parameters increased progressively with increasing rate of sulphur application. Bulb yield increased with successive increase in the level of sulphur up to $45 \mathrm{~kg} / \mathrm{ha}$ and thereafter decreased. The highest bulb yield (7.05 t/ha in 2005-06 and 7.22 t/ha in 200607) was achieved at $45 \mathrm{~kg} \mathrm{~S} / \mathrm{ha}$ and the control treatment receiving no fertilizer had the lowest yield (3.21 t/ha in 2005-06 in and $3.26 \mathrm{t} / \mathrm{ha}$ in 2006-07). The yield benefit for $45 \mathrm{~kg}$ sulphur per ha was $34.2 \%$ in $2005-06$ and $40.0 \%$ in 200607 over no sulphur. Sulphur at $45 \mathrm{~kg} /$ ha produced $54.5 \%$ and $54.9 \%$ higher yield over control treatment in both the years. The optimum and economic dose of sulphur for the yield of garlic were 44.0 and $43.6 \mathrm{~kg} / \mathrm{ha}$, respectively.
\end{abstract}

Keywords: Sulphur, garlic growth, and bulb yield

\section{Introduction}

Sulphur is the fourth major plant nutrient after nitrogen, phosphorus, and potassium. It is essential for the synthesis of amino acids like cystine, cysteine, and methionine, a component of vitamin A and activates certain enzyme systems in plants (Havlin et al., 2004). Continuous removal of S from soils through plant uptake has led to widespread S deficiency and affected soil S budget (Aulakh, 2003) all over the world. Sulphur deficiency in Bangladesh soils is becoming widespread and acute. Use of high analysis fertilizers, such as urea, TSP, MoP, and ammonium phosphate, cultivation of modern varieties, increasing cropping intensities and limited application of organic manure have all contributed to the intensification of the $\mathrm{S}$ deficiency problem in Bangladesh soils (Islam, 2008). Garlic (Allium sativum L.) is the second most important spice crops next to onion (Bose and Som, 1990). It is taken for curing many human diseases. (Augusti, 1997; 2000; Durak et al., 2004; and Pitman, 2008).

\footnotetext{
${ }^{1}$ Senior Scientific Officer, RARS, Bangladesh Agricultural Research Institute (BARI), Jamalpur, ${ }^{2}$ Professor, Department of Soil Science, Bangladesh Agricultural University (BAU), Mymensingh, ${ }^{3}$ Professor, Department of Horticulture, BAU, Mymensingh, Bangladesh.
} 
At present, 1.02 million tons garlic bulbs are produced in Bangladesh against the requirement of 2.19 million tons (BBS, 2006). The average yield of garlic in our country is $3.82 \mathrm{t} / \mathrm{ha}$ which is very low (BBS, 2006) compared to $11.07 \mathrm{t} / \mathrm{ha}$ produced by garlic producing countries of the world. Lower yield of garlic in Bangladesh is mainly due to degradation of soil fertility, imbalanced fertilization, and lack of proper crop management practices. Sulphur application in garlic enhances the uptake of N, P, K, and Ca by the crop (Hossain, 1997). Report is available that apart from NPK fertilizer, sulphur can play a vital role in increasing the yield of garlic (Ahmed et al., 1988). Plant height, number of leaves/plant, cloves/bulb, diameter and weight of bulb and bulb yield increased with the application of sulphur (Nasrin et al., 2007). Alam (1995) stated that sulphur played an appreciable role in increasing yield by increasing the number of leaves/plant, plant height, number of cloves/bulb and fresh and dry weight of bulb. Combined effect of sulphur and boron on the emergence of seedling, plant height, bulb yield, and yield contributing characters was found significant (Islam and Huq, 1999). The present investigation was, therefore, undertaken to see the impact of sulphur applicantion on growth and yield of garlic crop.

\section{Materials and Method}

The experiment was conducted at the research field of Regional Agricultural Research Station (RARS) Jamalpur in two consecutive rabi seasons of 2005-06 and 2006-07. The objective of the study was to find out an optimum dose of sulphur for garlic production. The soil of the experimental field was silt loam in texture belonging to Sonatola Soil Series under the AEZ 9: Old Brahmaputra Floodplain (FAO, 1971). Organic matter content of the soil was low. The soil was acidic in nature. Total $\mathrm{N}$ and exchangeable $\mathrm{K}$ status of the soil were also low. The available phosphorus, sulphur, boron, and zinc were either at par or below the critical level (Table 1). Six levels of sulphur viz., 0, 15, 30, 45, 60, and $75 \mathrm{~kg} /$ ha were used in the experiment. There was a control treatment in the study. The fertilizer package $\mathrm{N}_{150} \mathrm{P}_{60} \mathrm{~K}_{120} \mathrm{Zn}_{4} \mathrm{~B}_{1} \mathrm{~kg}$ /ha was applied to each plot as blanket dose. The experiment was carried out in randomized complete design with three replications. The unit plot size was $2.0 \mathrm{~m} \times 1.5 \mathrm{~m}$. Seeds of garlic (cv. BARI Rasun-1) were sown on first week of November at spacing of $15 \mathrm{~cm}$ and $10 \mathrm{~cm}$. The crop was harvested on 28 March 2006 and 30 March 2007 when the plants attained maturity and showing drying up of most of the leaves and bending over. Harvesting was done with the help of a Nirani. Care was taken to avoid any kind of bulb injury during lifting. Intercultural operations were done as and whenever required. Data on plant growth, yield parameters, and bulb yield were taken and analyzed through MS STAT programme. The DMRT test was used for mean separations of the studied parameters. 
Table 1. Nutrient status of the initial soil.

\begin{tabular}{lc}
\hline \multicolumn{1}{c|}{ Soil parameters } & Values \\
\hline $\mathrm{pH}(1: 2.5$ Soil-water) & 5.80 \\
Bulk density (g/cm) & 1.43 \\
Exchangeable K (c mol/kg) & 0.12 \\
Exchangeable Ca (c mol/kg) & 3.60 \\
Exchangeable Mg (c mol/kg) & 1.05 \\
Organic matter (\%) & 1.07 \\
Total N (\%) & 0.06 \\
Available P (mg/kg) & 14.5 \\
Available S (mg/kg) & 13.6 \\
Available Zn (mg/kg) & 1.14 \\
Available B (mg/kg) & 0.18 \\
\hline
\end{tabular}

\section{Results and Discussion}

\section{Plant height}

Sulphur application showed a significant variation in plant height at different days after planting except at 30 DAP (Table 2). Plant height increased gradually with increasing the levels of sulphur up to $45 \mathrm{~kg} / \mathrm{ha}$ beyond which it decreased. The tallest plants $(71.5 \mathrm{~cm})$ was recorded in plot fertilized with $45 \mathrm{~kg} \mathrm{~S} / \mathrm{ha}$, which was statistically similar to that recorded in $30 \mathrm{~kg} \mathrm{~S} / \mathrm{ha}(70.8 \mathrm{~cm})$. The shortest plants $(44.3 \mathrm{~cm})$ were found in control plots. Plant height recorded in 2006-07 across the treatments followed the pattern similar to those observed in 2005-06. Increased plant height with increased sulphur fertilization was also reported by Vachhani and Patel (1993); Jalil (1998) and Alam (1995).

\section{Number of leaves/plant}

The effect of sulphur on the production of leaves was found to be significant at different DAP (Table 2). At 110 DAP, the number of leaves/plant was maximum (9.0) in treatment with $45 \mathrm{~kg} \mathrm{~S} / \mathrm{ha}$, while the minimum number (6.67) was recorded in plot where no fertilizer was applied. In 2006-07, there was no significant variation in number of leaves/plant at 50,70, and 90 DAP, whereas at 30 and 110 DAP as well as at harvest, it differed significantly. The maximum number of leaves/plant (8.23) was recorded in $45 \mathrm{~kg}$ S/ha, which was comparable to those recorded in other sulphur treatments except sulphur control plot and the minimum (6.80) was observed in plants with no fertilizers. 
Table 2. Effects of sulphur (S) on plant height at 20-day interval.

\begin{tabular}{|c|c|c|c|c|c|c|c|c|c|c|}
\hline \multirow{3}{*}{$\begin{array}{l}\text { Sulphur } \\
\text { ( kg/ha) }\end{array}$} & \multicolumn{10}{|c|}{ Plant height at different DAP (cm) } \\
\hline & \multicolumn{5}{|c|}{ 2005-06 } & \multicolumn{5}{|c|}{ 2006-07 } \\
\hline & 30 & 50 & 70 & 90 & 110 & 30 & 50 & 70 & 90 & 110 \\
\hline 0 & $22.2 \mathrm{ab}$ & $32.3 \mathrm{c}$ & $37.5 \mathrm{~b}$ & $50.4 \mathrm{c}$ & $56.4 \mathrm{~d}$ & $24.1 \mathrm{ab}$ & $33.8 \mathrm{a}$ & $39.1 \mathrm{bc}$ & $51.1 \mathrm{c}$ & $57.4 \mathrm{e}$ \\
\hline 15 & $22.6 \mathrm{a}$ & $35.2 \mathrm{ab}$ & $40.9 \mathrm{~b}$ & $56.1 \mathrm{~b}$ & $63.1 \mathrm{c}$ & $24.4 \mathrm{ab}$ & 33.9 a & $39.9 \mathrm{ab}$ & $56.7 \mathrm{~b}$ & $64.8 \mathrm{~cd}$ \\
\hline 30 & $23.2 \mathrm{a}$ & $36.0 \mathrm{a}$ & $41.3 \mathrm{~b}$ & $60.5 \mathrm{ab}$ & $70.8 \mathrm{a}$ & $24.4 \mathrm{ab}$ & $34.5 \mathrm{a}$ & $43.3 \mathrm{ab}$ & $61.5 \mathrm{a}$ & $69.3 \mathrm{ab}$ \\
\hline 45 & 22.9 a & $35.4 \mathrm{ab}$ & $46.3 \mathrm{a}$ & $62.7 \mathrm{a}$ & $71.5 \mathrm{a}$ & $23.7 \mathrm{ab}$ & $36.4 \mathrm{a}$ & $44.3 \mathrm{a}$ & $63.7 \mathrm{a}$ & $71.5 \mathrm{a}$ \\
\hline 60 & $23.2 \mathrm{a}$ & $33.9 \mathrm{~b}$ & $41.9 \mathrm{~b}$ & $56.4 \mathrm{~b}$ & $66.9 \mathrm{~b}$ & $24.8 \mathrm{ab}$ & $34.5 \mathrm{a}$ & $41.9 \mathrm{ab}$ & $61.9 \mathrm{a}$ & $66.4 \mathrm{bc}$ \\
\hline 75 & $22.6 \mathrm{a}$ & $34.4 \mathrm{ab}$ & $39.9 \mathrm{~b}$ & $57.0 \mathrm{~b}$ & $66.4 \mathrm{~b}$ & $26.2 \mathrm{a}$ & $37.0 \mathrm{a}$ & $43.1 \mathrm{ab}$ & $62.0 \mathrm{a}$ & $61.8 \mathrm{~d}$ \\
\hline Control (No fert.) & $20.7 \mathrm{~b}$ & $28.1 \mathrm{~d}$ & $32.3 \mathrm{c}$ & $40.2 \mathrm{~d}$ & $44.3 \mathrm{~d}$ & $21.5 \mathrm{~b}$ & $29.7 \mathrm{~b}$ & $35.3 \mathrm{c}$ & $44.7 \mathrm{~d}$ & $43.9 \mathrm{f}$ \\
\hline CV (\%) & 3.62 & 2.64 & 6.11 & 5.40 & 4.28 & 6.89 & 5.92 & 5.76 & 8.68 & 3.87 \\
\hline
\end{tabular}

Figures in a column having same letters do not differ significantly at 5\% level of probability, Every treatment received $N_{150} \mathrm{P}_{60} \mathrm{~K}_{120} \mathrm{Zn}_{4}$ $\mathrm{B}_{1} \mathrm{~kg} / \mathrm{ha}$ 
Table 3. Effects of sulphur on number of leaves/plant at regular 20-day interval.

\begin{tabular}{c|c|c|c|c|c|c|c|c|c|c}
\hline \multirow{2}{*}{$\begin{array}{c}\text { Sulphur } \\
\text { (kg/ha) }\end{array}$} & \multicolumn{9}{c}{ Number of leaves/plant at different DAP } \\
\cline { 2 - 11 } & \multicolumn{9}{c}{$2005-06$} & \multicolumn{5}{c}{$2006-07$} \\
\cline { 2 - 11 } & 30 & 50 & 70 & 90 & 110 & 30 & 50 & 70 & 90 & 110 \\
\hline 0 & $4.80 \mathrm{ab}$ & $5.40 \mathrm{bc}$ & $6.40 \mathrm{ab}$ & $7.00 \mathrm{~b}$ & $7.73 \mathrm{~b}$ & $4.17 \mathrm{ab}$ & 5.37 & 6.42 & 6.73 & $7.50 \mathrm{~b}$ \\
15 & $4.90 \mathrm{a}$ & $5.73 \mathrm{ab}$ & $6.93 \mathrm{ab}$ & $7.17 \mathrm{ab}$ & $8.47 \mathrm{a}$ & $4.23 \mathrm{ab}$ & 5.47 & 6.47 & 6.80 & $7.83 \mathrm{ab}$ \\
30 & $5.00 \mathrm{a}$ & $5.87 \mathrm{ab}$ & $6.23 \mathrm{ab}$ & $7.20 \mathrm{ab}$ & $8.80 \mathrm{a}$ & $4.20 \mathrm{ab}$ & 5.70 & 6.40 & 6.80 & $8.07 \mathrm{ab}$ \\
45 & $4.80 \mathrm{ab}$ & $5.87 \mathrm{ab}$ & $7.10 \mathrm{a}$ & $7.47 \mathrm{ab}$ & $9.00 \mathrm{a}$ & $4.17 \mathrm{ab}$ & 5.83 & 6.17 & 6.47 & $8.23 \mathrm{a}$ \\
60 & $4.80 \mathrm{ab}$ & $5.57 \mathrm{ab}$ & $6.80 \mathrm{ab}$ & $7.33 \mathrm{ab}$ & $8.87 \mathrm{a}$ & $4.23 \mathrm{ab}$ & 5.73 & 6.20 & 6.87 & $8.20 \mathrm{a}$ \\
75 & $4.90 \mathrm{a}$ & $6.10 \mathrm{a}$ & $6.70 \mathrm{ab}$ & $7.53 \mathrm{a}$ & $8.73 \mathrm{a}$ & $4.27 \mathrm{a}$ & 5.70 & 6.43 & 6.83 & $7.93 \mathrm{ab}$ \\
\hline Control & $4.40 \mathrm{~b}$ & $4.90 \mathrm{c}$ & $6.00 \mathrm{~b}$ & $6.27 \mathrm{c}$ & $6.67 \mathrm{c}$ & $4.07 \mathrm{~b}$ & 5.37 & 5.87 & 6.27 & $6.80 \mathrm{c}$ \\
(No fert.) & & & & & & & & & & \\
CV(\%) & 4.84 & 5.40 & 0.95 & 0.47 & 4.94 & 2.41 & 5.28 & 7.07 & 5.27 & 4.24
\end{tabular}

Figures in a column having same letters do not differ significantly at $5 \%$ level of probability

Every treatment received $\mathrm{N}_{150} \mathrm{P}_{60} \mathrm{~K}_{120} \mathrm{Zn}_{4} \mathrm{~B}_{1} \mathrm{~kg} / \mathrm{ha}$

\section{Dry weight of leaves/plant}

Leaf dry weight/plant was affected significantly by sulphur fertilization at maximum growth stage of plant (Table 4). The highest leaf weight $(2.07 \mathrm{~g}$ in 2005-06 and $2.20 \mathrm{~g}$ in 2006-07) was recorded in $45 \mathrm{~kg} \mathrm{~S} / \mathrm{ha}$, which was significantly higher than the weights recorded in rest of the treatments. The plants grown without sulphur produced the lowest dry leaf weight (1.38 $\mathrm{g}$ in 2005-06 and $1.32 \mathrm{~g}$ in 2006-07).

\section{Dry weight of plant}

Sulphur had significant effects on dry plant weight at maximum growth stage (Table 4). It increased progressively with increasing the levels of sulphur from 0 to $45 \mathrm{~kg} / \mathrm{ha}$. The maximum plant dry weight $(4.20 \mathrm{~g})$ was obtained from $45 \mathrm{~kg}$ $\mathrm{S} /$ ha and the minimum (1.73 g/plant) was recorded in control treatment. This might be due to maximum vegetative growth which enhanced maximum photosynthesis and accumulation of more dry matter in plants. The increase in dry plant weight due to sulphur fertilization indicates a positive role of sulphur on vegetative growth of plant. 
Table 4. Effect of different levels of sulphur on dry weight of leaves, root and single plant weight at the maximum stage of growth.

\begin{tabular}{c|ll|l|l|l}
\hline \multirow{2}{*}{$\begin{array}{c}\text { Sulphur } \\
\text { (kg/ha) }\end{array}$} & \multicolumn{2}{|c|}{$\begin{array}{c}\text { Dry wt of leaves/plant } \\
\text { (g) }\end{array}$} & \multicolumn{2}{c|}{$\begin{array}{c}\text { Dry wt of roots/plant } \\
\text { (g) }\end{array}$} & $\begin{array}{c}\text { Dry wt of } \\
\text { single plant } \\
\text { (g) }\end{array}$ \\
\cline { 2 - 6 } & $2005-06$ & $2006-07$ & $2005-06$ & $2006-07$ & $2006-07$ \\
\hline 0 & $1.38 \mathrm{~d}$ & $1.32 \mathrm{de}$ & $0.16 \mathrm{~b}$ & $0.16 \mathrm{~b}$ & $2.77 \mathrm{~d}$ \\
15 & $1.56 \mathrm{c}$ & $1.67 \mathrm{bc}$ & $0.18 \mathrm{ab}$ & $0.20 \mathrm{a}$ & $3.17 \mathrm{c}$ \\
30 & $1.84 \mathrm{~b}$ & $1.80 \mathrm{~b}$ & $0.20 \mathrm{a}$ & $0.20 \mathrm{a}$ & $3.83 \mathrm{~b}$ \\
45 & $2.07 \mathrm{a}$ & $2.20 \mathrm{a}$ & $0.21 \mathrm{a}$ & $0.22 \mathrm{a}$ & $4.20 \mathrm{a}$ \\
60 & $1.76 \mathrm{~b}$ & $1.55 \mathrm{a}$ & $0.21 \mathrm{a}$ & $0.22 \mathrm{a}$ & $3.10 \mathrm{a}$ \\
75 & $1.40 \mathrm{~d}$ & $1.44 \mathrm{bcd}$ & $0.20 \mathrm{a}$ & $0.20 \mathrm{a}$ & $2.88 \mathrm{~d}$ \\
\hline Control & $1.04 \mathrm{e}$ & $1.08 \mathrm{~cd}$ & $0.10 \mathrm{c}$ & $0.11 \mathrm{c}$ & $1.73 \mathrm{e}$ \\
(No fert.) & & & & & \\
\hline CV (\%) & 4.95 & $8.81 \mathrm{e}$ & 10.79 & 11.55 & 3.70 \\
\hline
\end{tabular}

Figure in a column having same letter do not differ significantly at $5 \%$ level of probability.

Every treatment received $\mathrm{N}_{150} \mathrm{P}_{60} \mathrm{~K}_{120} \mathrm{Zn}_{4} \mathrm{~kg} \mathrm{~B}$ / ha as a blanket dose.

\section{Dry weight of root/plant}

Dry weight of roots/plant at harvest significantly affected by sulphur application (Table 4). The maximum root dry weight/plant (0.21 g in 2005-06 and $0.22 \mathrm{~g}$ in 2006-07) was recorded in the same dose of sulphur fertilizer.

\section{Number of cloves/bulb}

Application of sulphur significantly increased yield attributes of garlic over control in both the years. The maximum number of cloves/bulb (19.2 in 2005-06 and 22.1 in 2006-07) was recorded at $45 \mathrm{~kg} \mathrm{~S} / \mathrm{ha}$, the minimum values (13.1 in 2005-06 and 16.9 in 2006-07) were recorded in plants where no fertilizers was applied (Table 5).

\section{Bulb length}

Significant variation in bulb length was observed due to application of sulphur (Table 5). The maximum length of bulb at harvest $(2.95$ and $3.06 \mathrm{~cm})$ was recorded at $45 \mathrm{~kg} \mathrm{~S} / \mathrm{ha}$. Results revealed that bulb length showed a decreasing trend with the increasing levels of $S$ after $45 \mathrm{~kg} / \mathrm{ha}$. The minimum length of bulb $(1.96 \mathrm{~cm}$ and $2.02 \mathrm{~cm}$ ) was observed in plants with no application of fertilizers.

\section{Diameter of bulb}

Sulphur application has created significant impact on bulb diameter of garlic (Table 5). The highest bulb diameter $(3.19 \mathrm{~cm}$ in $2005-06$ and $3.57 \mathrm{~cm}$ in 2006- 
07) was recorded in treatment receiving $45 \mathrm{~kg} \mathrm{~S} / \mathrm{ha}$, while the lowest $(2.24 \mathrm{~cm}$ in 2005-06 and $2.31 \mathrm{~cm}$ in 2006-07) was observed in control treatment. Sulphur application at $45 \mathrm{~kg} \mathrm{~S} /$ ha favoured plant growth and development thus producing large bulbs. Nasrin et al. (2008) also found large size bulbs with higher doses of sulphur (40 to $60 \mathrm{~kg} / \mathrm{ha}$ ).

Table 5. Effect of different levels of sulphur on yield components of garlic.

\begin{tabular}{|c|c|c|c|c|c|c|c|c|}
\hline \multirow[t]{2}{*}{$\begin{array}{l}\text { Sulphur } \\
\text { (kg/ha) }\end{array}$} & \multicolumn{2}{|c|}{$\begin{array}{l}\text { Bulb length } \\
(\mathrm{cm})\end{array}$} & \multicolumn{2}{|c|}{$\begin{array}{l}\text { Bulb diameter } \\
\qquad(\mathrm{cm})\end{array}$} & \multicolumn{2}{|c|}{$\begin{array}{c}\text { Fresh wt of single } \\
\text { bulb } \\
\text { (g) }\end{array}$} & \multicolumn{2}{|c|}{ No. of cloves/bulb } \\
\hline & 2005-06 & 2006-07 & 2005-06 & 2006-07 & 2005-06 & 2006-07 & 2005-06 & 2006-07 \\
\hline 0 & $2.38 \mathrm{~b}$ & $2.46 \mathrm{c}$ & $2.53 \mathrm{~d}$ & $2.58 \mathrm{~cd}$ & $11.7 \mathrm{~b}$ & $12.2 \mathrm{c}$ & $16.8 \mathrm{~b}$ & 19.2 \\
\hline 15 & $2.68 \mathrm{a}$ & $2.76 \mathrm{~b}$ & $2.79 \mathrm{~cd}$ & $2.93 \mathrm{bc}$ & $12.3 \mathrm{~b}$ & $14.4 \mathrm{ab}$ & $18.6 \mathrm{a}$ & 18.9 \\
\hline 30 & $2.82 \mathrm{a}$ & $2.90 \mathrm{ab}$ & $3.13 \mathrm{ab}$ & $3.25 \mathrm{ab}$ & $14.1 \mathrm{a}$ & $15.9 \mathrm{a}$ & $18.4 \mathrm{a}$ & 18.9 \\
\hline 45 & $2.95 \mathrm{a}$ & $3.06 \mathrm{a}$ & 3.19 a & 3.57 a & $14.3 \mathrm{a}$ & $16.0 \mathrm{a}$ & $19.2 \mathrm{a}$ & 22.1 \\
\hline 60 & $2.73 \mathrm{a}$ & $2.87 \mathrm{ab}$ & 2.87 bc & $3.06 \mathrm{ab}$ & $14.0 \mathrm{a}$ & 13.9 abc & $16.1 \mathrm{~b}$ & 16.9 \\
\hline 75 & $2.83 \mathrm{a}$ & $2.78 \mathrm{ab}$ & $2.80 \mathrm{~cd}$ & 2.94 bc & $13.7 \mathrm{a}$ & $13.0 \mathrm{bc}$ & $18.6 \mathrm{a}$ & 18.8 \\
\hline $\begin{array}{c}\text { Control } \\
\text { (No fert.) }\end{array}$ & $1.96 \mathrm{c}$ & $2.02 \mathrm{~d}$ & $2.24 \mathrm{e}$ & $2.31 \mathrm{~d}$ & $8.31 \mathrm{c}$ & $8.93 \mathrm{~d}$ & $13.1 \mathrm{c}$ & 16.9 \\
\hline CV (\%) & 6.18 & 5.50 & 5.28 & 6.65 & 3.80 & 8.30 & 5.11 & 14.8 \\
\hline
\end{tabular}

Figures in a column having same letter do not differ significantly at $5 \%$ level of probability.

Every treatment received $\mathrm{N}_{150} \mathrm{P}_{60} \mathrm{~K}_{160} \mathrm{Zn}_{4} \mathrm{~kg} /$ ha as a blanket dose.

\section{Weight of bulb}

Significant variations in fresh weight of bulb at harvest was observed due to application of different doses of sulphur (Table 5). The maximum weight of fresh bulb (14.3 g in 2005-06 and $16.0 \mathrm{~g}$ in 2006-07) was obtained at $45 \mathrm{~kg} \mathrm{~S} / \mathrm{ha}$. This might be due to adequate nutrient supply which favoured in enlaraging the bulb, this increased the weight of bulb. The result is in conformity with the findings of Nasiruddin et al. (1993) who reported that application of both potassium and sulphur either individually or in combined increased plant height, leaf production, bulb diameter, bulb weight as well as the bulb yield. The minimum weight of bulb (8.31 g and $8.93 \mathrm{~g}$ ) was observed in the control treatment. 


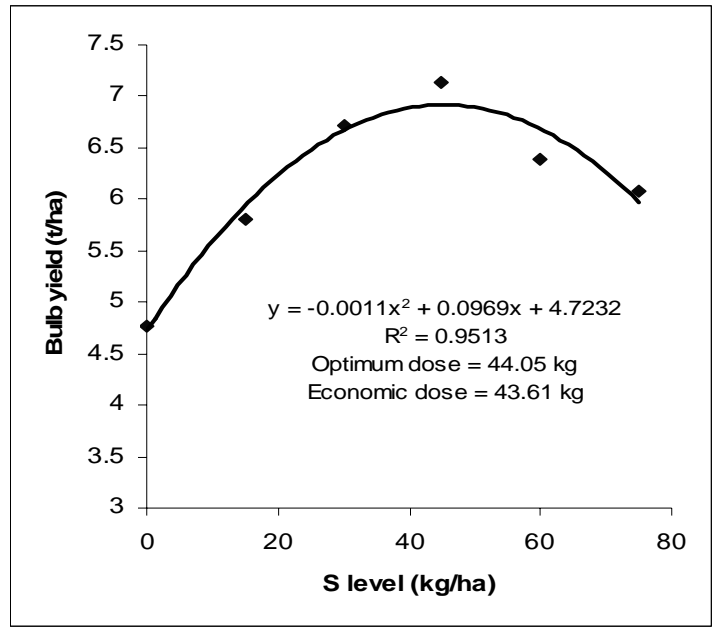

Figure 1.Relationship between sulphur levels and bulb yield

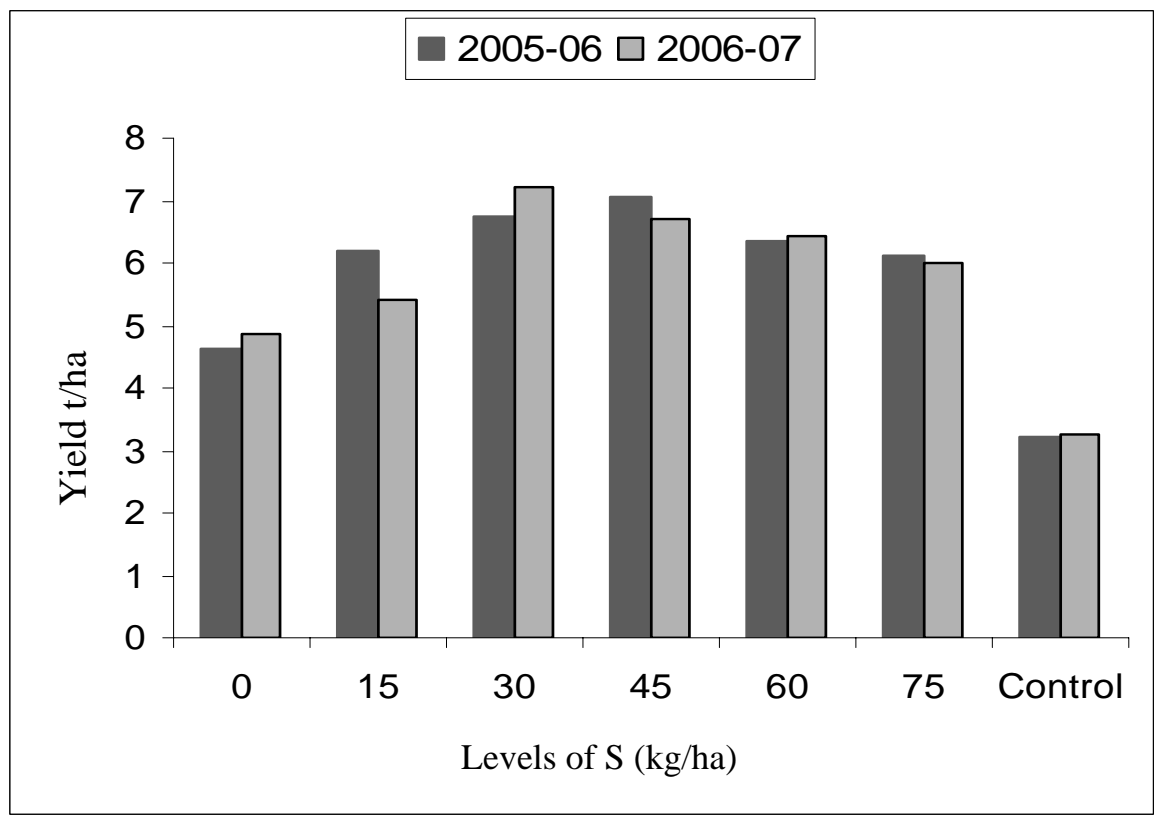

Figure 2. Effect of different levels of $S$ on the yield of garlic

\section{Bulb yield}

Bulb yield of garlic was greatly influenced by sulphur fertilization (Fig. 2). The highest bulb yield (7.05 t/ha in 2005-06 and 7.22 t/ha in 2006-07) was achieved 
at $45 \mathrm{~kg} \mathrm{~S} /$ ha and the control treatment receiving no fertilizer had the lowest yield (3.21 t/ha in 2005-06 and $3.26 \mathrm{t} / \mathrm{ha}$ in 2006-07). The maximum bulb yield obtained at $45 \mathrm{~kg} \mathrm{~S} / \mathrm{ha}$ was due to tallest plants, maximum number of leaves/plant, maximum cloves/bulb, and heaviest bulbs produced in the treatment that had led to produce significantly higher yield. The yield benefit for $45 \mathrm{~kg}$ sulphur/ha was $34.2 \%$ in $2005-06$ and $40.0 \%$ in $2006-07$ over no sulphur. Again it was found that $45 \mathrm{~kg} \mathrm{~S} /$ ha produced $54.5 \%$ and $54.9 \%$ higher yield in both the years, respectively, over control treatment. The result is in conformity with the findings of Anwar et al. (1996) and Nasrin et al. (2008). It is important to note that bulb yield beyond $45 \mathrm{~kg} / \mathrm{ha}$ sulphur application decreased with increasing levels of sulphur. The result is in agreement with the findings of Alam (1995). Bulb yield increased with successive increase in the level of sulphur up to 45 $\mathrm{kg} / \mathrm{ha}$ and thereafter decreased. This might be an imbalance or antagonistic effect on plant nutrition that resulted in the reduction of yield. There was a quantum jump in yield due to sulphur application suggesting that the soil was deficient in sulphur that resulted in a big yield differences with 30 and $45 \mathrm{~kg} \mathrm{~S} / \mathrm{ha}$. The relationship between the sulphur rates and the yields were explained by polynomial models $\left(\mathrm{Y}=\mathrm{a}+\mathrm{bx}+\mathrm{cx}^{2}\right.$ ) (Fig. 1). The value of $\mathrm{R}^{2}=0.9513$ indicates that different $\mathrm{S}$ levels can attribute to $95 \%$ of the variation in yield. The optimum and economic yield of garlic estimated from the regression equation were 44.0 and $43.6 \mathrm{~kg} / \mathrm{ha}$, respectively. Above the said optimum dose there is a possibility of loosing certain amount yield.

\section{References}

Ahmed, M. K., D. K. Aditya and M.A. Siddique. 1988. Effects of nitrogen and sulphur application on the growth and yield of onion cv. Faridpur Bhatti. Bangladesh Hort. 46 (1):36-41.

Alam, M. D. 1995. Effect of Paclobutrozol and S fertilizer on the growth yield and sulphur content of garlic. M .S Thesis, Bangladesh Agril. Univ., Mymensingh. pp. 92-95.

Anwar, M.N., M.S. Huq, M. J. U. Sarkar, S. K. Nandy and M.S. Islam. 1996. Effects of nitrogen, phosphorus, potassium, sulphur and zinc on garlic. Bangladesh Hort. 24 (1 \& 2):12-16.

Augusti, K.T. 1977. Hyposholesterolacmic effect of garlic (Allium Sativum L.). Indian J. Expt. Biol. 15 (6): 489-490.

Aulakh, M. S. 2003. Crop response to sulphur nutrition. In: Y. P. Abrol and A. Ahmad (eds.) Sulphur in Plants. Kluwer Academic Publ. Dordrecht. pp. 341-354.

BBS (Bangladesh Bureau of Statistics). 2006. Yearbook of Agricultural Statistics of Bangladesh, Sattistics Division, Ministry of Planning, Government of the People's Republic of Bangladesh, Dhaka 1215. 
Bose, T. K. and M. G. Som. 1990. Vegetable Crops in India. Published by B. Mitra and Naya Prakash, Calcutta, India. pp.583-601.

Brahma, S. and M. N. Yousuf. 2008. Effect of nitrogen and potassium on the growth and yield of garlic. Research Report for 2007-2008. Spices Research Centre. BARI Shibgong, Bogra. pp. 77-81.

Durak, I. M. Kavutch, B. Aytac, 2004. Effect of garlic extract consumptions on blood lipid and oxidant/ antioxidant parameters in human with high blood cholesterol. J. Nutr. Biochem. 15 (6):373-377.

FAO (Food and Agriculture Organization). 1971. United Nations Development Programme. Soil Survey Project of Bangladesh. Soil Resources Technical Report. 3: 101-159.

Havlin, J. L., J. D. Beaton, S. L. Tisdale and W. L. Nelson. 2004. Soil fertility and fertilizers. An introduction to nutrient management. $7^{\text {th }}$ edn. Pearson Education Inc. Singapore. p.221.

Hossain, M. M. 1997. Effect of different levels of nitrogen and potash on the growth and yield of garlic. M.S. Thesis. Dept. Hort. Bangladesh Agril. Univ., Mymensingh p. 65.

Islam, M. F. and M. F. Huq. 1999. Integrated nutrient management with inorganic fertilizers and green manure in some dominant cropping patterns. In: Integrated nutrient management for crop production and soil fertility. M. Fokrul., D. A. Chowdhury, G. M. Panaullah, M.U. Miah, J. Rijpma, and M. F. Haque, M. F. (Eds), BARI, Gazipur. pp 55-72.

Islam, M.S. 2008. Soil Fertility History, Present Status and Future Scenario in Bangaldesh. Bangladesh J. Agric. and Environ. 4: 129-151.

Jalil, M. A. 1998. Effect of planting time, paclobutrazol and S fertilizers on the growth, yield and S content of garlic. M S Thesis. Bangladesh Agril. Univ., Mymensingh. p 88.

Nasiruddin, K. M., A. M. Farooque and M .A. Baten. 1993. Effect of potassium and sulphur on growth and yield of onion. Bangladesh J. Agril. Sci. 20 (1): 35-40.

Nasrin, S., M. A. Hossain and A.T. M. Farid. 2007. Integrated nutrient management for garlic (Allium cepa L.). Bangladesh J. Agril. Sci. 34 (1): 45-48.

Nasrin, S., M. N. Yousuf, M.M. Haque and A.N.M. Mamun. 2008. Response of garlic (Allium sativum L.) varieties to sulphur fertilizer, Research Report for 2007-08. Spices Research Centre, Shibganj, Bogra, Bangladesh. p.87.

Pitman, D. 2008. Medina Research Station and John Burt, Horticulture Adviser, South Perth.

Vachhani, M. U. and Z. G. Patel. 1993. Growth and yield of onion (Allium cepa L.) as influenced by nitrogen, phosphorus and potash under South Gujrat condition. Prog. Hort. 25 (3-4):166-167. 